\title{
The Relationship Between Athletes' Psychological Skills and Personality Traits in Turkey Olympic Preparation Center (TOPC)
}

\section{Elif Kübra Geneșke*, Ahmet Gökhan Yazıcı}

Physical Education and Sports, Kazim Karabekir Faculty of Education,Atatürk University, Erzurum, Turkey

Study Area: Erzurum, Turkey

Coordinates: $39^{\circ} 54^{\prime} 31$ ? N; $41^{\circ} 16^{\prime} 37$ ? E

Key words: Difficulties, Learning, Concentration, Goal setting

\section{Abstract}

The sample of this research; selected by random sampling method from TOHM in Ankara province, continuing their education sports, athletes of different branch 57 female, 75 men constitutes a total of 132 people. In this research, relational survey model, one of the quantitative research methods, was used. To determine the relationship between Ankara in TOHM atleths' psychological skills and personality traits in order to specify demographic information in this survay 'Personal Information Form' 'for psychological skills of the athlets' evaluation questionnaire of Psychological Skills of Athlets' and determine the athlets' personality traits Five Factor Personality Inventory were used. The correlation was found between the psychological skills and personality traits of the athletes, a positive significant relationship was found.

intense competition (Altun \& Koçak, 2015). The concept of the sport is defined as a game that has international rules and standards and is based on competition (Weinberg et al., 2015). Doing sports also has positive effects on people's social and individual character development (Danaci, 2008; Yazici et al., 2019). Sport has always existed in human life. The interaction of sports, which is affected by every development in the world, with different disciplines, is inevitable (Murathan \& Murathan, 2019). Sports, which is among the educational activities, provides the power of expressing common goals with one's own self and the feeling of appreciating the individual called the opponent (Ilhan, 2008). Physical Education and sports significantly contribute to the mental, psychological, and physical development of individuals of all ages, especially children (Akoguz et al., 2016). Concordantly, as stated by emphasizing our Constitution our main goal in sports training is the adoption of the habits and order of doing sports to all citizens and the education of elite athletes who can prove themselves at a high level by exploring children and young people who are talented in sports, centering the Olympic understanding of these discovered people (D.P.T., 2000).

There are two major state-backed institutions that have boarding and day student options to train senior athletes in Turkey. These are Turkey Olympic Preparation Centers and Athlete Training Centers.

In order to provide a common and standard application in the management and administration of TOPCs, which with its intercultural unifying effect and increasingly 
develop in terms of quality and quantity over time, "Regulation on Establishment, Operation, Duties, Authority, and Responsibility of Olympic Preparation Centers" entered into force by being published in the Official Gazette dated 11 April 2015 and numbered 29323 (Official Gazette, 2015).

It is acceptable to see Turkey Olympic Preparation Centers including athletes, the coaches, friends, and other employees of the center as a family. In this context, article 59 of our Constitution includes such a statement; "The state takes measures to improve the physical and mental health of Turkish citizens of all ages and encourages the spread of sports among the masses. The state protects successful athletes." The duties and responsibilities of Turkey Olympic Preparation Centers on athletes are clearly seen in the light of the provisions ( $\mathrm{Url}, \mathbf{2 0 2 0})$.

Even if the science of psychology is considered as a branch of science that examines the behavior and mental processes of people, the diversity of behaviors and mental processes of any human being, being multidimensional and having a structure that affects and influences diversifies and creates a complex state. In this respect, the science of psychology analyses different aspects of people by dividing them into certain sub-fields (Cüceloglu, 2009).

Psychology has its own therapy and intervention techniques. Sports psychology has also developed its own theories and intervention methods starting from 1979 (Brewer, 2009). Sports psychology is a branch of science that analyses athletes' thoughts and behaviors in all details by adhering to the cause-effect relationship and tries to improve the success of athletes and trainers with various mental abilities (Koruç, 1998). The competitive environment in sports and the fact that winning is always at the forefront should be developed in the physical and psychological strength of athletes (Yazici et al., 2019).

Personality is among the most striking subjects compared to other subjects in psychology (Somer et al., 2004; Feist, 1990). Personality theories are included in the entire history of psychology. From this point of view, they were influenced by the ideas of classical philosophers such as Hippocrates, Plato, and Aristo about the individual and the knowledge revealed by the great philosophers and scientists who lived in the periods after them (Yanbasti, 1996).

\section{Methodology:}

This section contains information about the research model, population and sample, data collection tools, data collection, and analysis.

The population of the research consists of athletes in Turkey Olympic Preparation Center (TOPC). The sample of the research includes a totally of 132 athletes in Ankara at the period of 2018-2019 from different branches (20 people from Athletics; 20 people from Fencing, 15 people from Weightlifting, 13 people from Judo, 15 people from Karate, 16 people from Taekwando, 11 tennis players \& 22 swimmers). $57 \%$ of the participants are women and $75 \%$ are men.

In this study, the relational screening model, which is among the quantitative research methods, has been used. Correlational survey models are research models that aim to rank by determining the presence or level of change between variables that have two or more numbers. In such screening models, it is possible to interpret the relationships and make a judgment as well as the possibility of not having a cause and effect relationship. Relational screening is carried out in two ways:" the type of correlation" and "the relation by comparison". Correlation type relationship has been used in this study. There are three situations in correlation-type relationships as 'there is no relationship between two variables', 'there is a relationship and it is directly proportional', and 'there is a relationship and it is inversely proportional'. The correlation coefficient takes a value between -1 and +1 . If the correlation coefficient takes a value close to o or o, the relationship is either absent or meaningless. As the correlation coefficient approaches +1 , there is a relationship and it is directly proportional, as the correlation coefficient approaches -1 , there is a relationship and this relation is inversely proportional" (Kincal, 2015).

The necessary permission has been taken from the Ministry of Youth and Sports before the research, and it has been applied to athletes in Turkey Olympic Preparation Center (TOPC). The application has been carried out face to face during the class hours of the athletes, with the permission of their teachers before the lesson. Necessary information has been provided to the athletes before the survey, and they have been monitored during the survey. "Personal Information Form" to determine the demographic information of this study, which was carried out in order to determine the relationship between the psychological skills and personality traits of TOPC athletes in Ankara, "The Evaluation of the Psychological Skills of Athletes" questionnaire for the psychological skills of the athletes and the "Five Factor Personality Inventory" to determine the personality traits have been used.

Windows Microsoft Word program for editing data and creating graphics in the writing process, Microsoft Excel spreadsheet program for entering and editing data primarily and SPSS 25 statistical package program for evaluating data and performing statistical tests have been used in the study.

The criterion of skewness and kurtosis between +1.5 and 1.5 has been used to display whether the data had a normal distribution (Tabachnick \& Fidell, 2013). According to the test results, it has been found that the data were distributed normally, and analyzes have been done accordingly. Due to the parametric nature of the study, while the T-Test has been used for independent tests for binary variables, the Anova Test has been carried out for 
three or more variables. Tukey analysis has been used for the significance of three or more variables among themselves. The correlation has been calculated by looking at the average values of the answers given by the participants. It has been found that the Pearson Correlation coefficient among the five-factor personality traits average values of the Athletes' Psychological Skills was positively calculated as $213^{*}$, that is, every increase trend in the Psychological Skills of the athletes increased in parallel with the FiveFactor Personality Traits and the significance value was found as $(\mathrm{p}=, 014)$. The average values of two different scales used for the reliability of the test have been taken, and the Cronbach Alpha coefficient value has been found as 0.706.

Validity and Reliability: in the research, a "personal information form" consisting of 7 questions has been prepared to determine the demographic information of the athletes. In the Information form, there are questions regarding age, gender, level of education, sport, sports, age, sports-type, etc. of the athletes in Turkey Olympic Preparation Center (TOPC) in Ankara.

In the second part, "Psychological Skill Assessment Scale", which was developed by Smith et al. (1995) and adapted into Turkish by Erhan by applying a validity and reliability test has been used (Erhan et al., 2015).

People who studied and developed this scale, which is a self-assessment tool to describe the psychological skills of athletes are Smith et al., (1995). This measurement tool, which was developed to determine the psychological skills of athletes, consists of 28 items in total. Each item of these 28 items consists of 7 sub-dimensions and each of these 7 sub-dimensions consists of 4 items. The scale, which includes 28 items in total, is in a 4-point Likert type scale structure.

The grading has been scored between o and 3 according to the expressions 'Almost never', 'Sometimes', 'Often' and 'Almost always'. The questions numbered 3,7,10,12, 19, and 23 of the scale are negative and they should be numbered reverse. Grading for sub-dimensions' ranges from o to 12, and an increase in the score obtained from the scale indicates that the athlete's psychological skills are good. Seven sub-dimensions are constituted by Smith et al., (1995). Definitions and item examples of these seven subdimensions aregiven below.

-Ability to Cope with Difficulties: This sub-scale measures whether an athlete can be positive, enthusiastic, calm, in control, and quickly get rid of his/her mistakes, even when the situation worsens. "For me, I maintain my emotional control no matter how things go". (Vanek, 1970).

-Being Open to Learning: It measures whether the athlete is open to learning and accepts constructive criticisms without personal perception and without worry. 'When a trainer or manager tells me how to correct a mistake I have made, I tend to perceive it personally and feel sorry (Erhan et al., 2015).

- Concentration: This sub-scale measures whether an athlete is easily distracted and concentrates on his/her task, even in unexpected adverse situations, both in training and during a match. 'I can focus my attention and forget distractions while doing sports' (Smith et al., 1995).

-Trust and Success Motivation: It measures whether an athlete is confident and positively motivated during training and matches. 'I make the most of my talent and skill' (Moran, 2004).

-Goal Setting and Mental Preparation: It measures whether an athlete sets specific performance goals and works in that direction. "I set my own performance goals for each training" (Suinn, 1980).

-Ability to Perform Better under Pressure: It measures whether an athlete performs better under pressure. "The more pressure there is during a game, the more I enjoy that game" (Altintas \& Akalan, 2008).

-No Worries: It measures whether an athlete is putting pressure on himself/herself for worrying that I will perform poorly or make mistakes 'I worry too much about what others think of my performance (Murphy \& Jowdy, 1992).

The Five-Factor Personality Inventory, which was developed by John et al., (1991) in order to determine the personality traits of trainers and adapted into Turkish by Evinç (2004) has been used. The inventory, consisting of 44 items, includes sub-dimensions of extraversion, emotional stability, openness to experience, agreeableness, and selfdiscipline, which are 5 major characteristics of personality. Scale items are graded as "strongly disagree" (1 point), "slightly disagree" (2 points), "neither agree nor disagree" (3 points), "slightly agree" (4 points), "totally agree" (5 points).

In the reliability analysis results created by Evinç (2004), the Alpha (a) coefficients of the inventory have been calculated as. 74 for Extraversion, .75 for Emotional Stability, .74 for Openness to Experience, .51 for Agreeableness and. 66 for Self-discipline, respectively.

Results:

In this part of the research, the findings obtained as a result of the analysis of the data collected with the data collection tool are included.

Table-1: Table 1.Findings of the Athletes Participating in the Study Regarding the Demographic Features

\begin{tabular}{lllllll}
\hline Parameter & Class & $\mathrm{N}$ & $\%$ & Class & $\mathrm{N}$ & $\%$ \\
\hline Gender & Female & 57 & 43.2 & Male & 75 & 56.8 \\
Age & $15-18$ & 52 & 39.4 & $19-22$ & 49 & 37.1 \\
& $23-26$ & 31 & 23.5 & & & \\
Educational & High Sch. & 55 & 41.7 & Undergrad. 61 & 46.2 \\
& Postgrad. & 16 & 12.1 & & & \\
Branch & Athletics & 20 & 15.2 & Fencing & 20 & 15.2 \\
& Wt. lifting & 15 & 11.4 & Judo & 13 & 9.3 \\
& Karate & 15 & 11.4 & Taekwando & 16 & 12.1 \\
& Tennis & 11 & 8.3 & Swimming & 22 & 16.7 \\
Sports Duration & $5-8$ years & 33 & 25 & $9-12$ years & 50 & 37.9 \\
& 13-16 years & 42 & 31.8 & $17-20$ years & 7 & $55 \cdot 3$ \\
Starting Age of & 6-8 yrs. & 40 & 30.3 & $9-11$ yrs. & 65 & 49.2 \\
Sports & $12-14$ yrs. & 20 & 15.2 & $15-17$ yrs. & 7 & $5 \cdot 3$ \\
Sports Type & Individual & 108 & 81.8 & Team & 24 & 18.2 \\
Total & & & 100 & & &
\end{tabular}

Total $132 \quad 100$ 
Table-2: The Psychological Skills Assessment Scale of the Athletes and the T-Test for the Gender Variable of its Sub-Factors

\begin{tabular}{|c|c|c|c|c|}
\hline & Gender & $\mathrm{N}$ & $\mathrm{X}$ & Ss \\
\hline \multicolumn{5}{|c|}{ Ability to Cope with Difficulties (T-test: $\mathrm{Sd}=130 ; \mathrm{T}=-1.125 ; \mathrm{p}=.263$ ) } \\
\hline & Female & 57 & 2.723 & .494 \\
\hline & Male & 75 & 2.823 & .511 \\
\hline \multicolumn{5}{|c|}{ Being Open to Learning (T-test: $\mathrm{Sd}=130 ; \mathrm{T}=-1.138 ; \mathrm{p}=.257$ ) } \\
\hline & Female & 57 & 2.912 & .535 \\
\hline & Male & 75 & 2.803 & .551 \\
\hline \multirow[t]{3}{*}{ Concentratio } & (T-test: $\mathrm{Sd}=130$; & $\mathrm{T}=-$ & 6o6; $p=$ & \\
\hline & Female & 57 & 2.561 & .480 \\
\hline & Male & 75 & 2.790 & .523 \\
\hline \multicolumn{2}{|c|}{ Trust and Success Motivation } & $(\mathrm{T}-\mathrm{t}$ & $\mathrm{Sd}=130$ & $-.801 ; p=.424)$ \\
\hline & Female & 57 & 2.837 & .567 \\
\hline & Male & 75 & 2.916 & .554 \\
\hline \multicolumn{5}{|c|}{ Goal Setting \& Mental Preparation (T-test: $\mathrm{Sd}=130 ; \mathrm{T}=-.474 ; \mathrm{p}=.636$ ) } \\
\hline & Female & 57 & 2.807 & .544 \\
\hline & Male & 75 & 2.856 & .657 \\
\hline \multicolumn{5}{|c|}{ Ability to Perform Better Under Pressure } \\
\hline & & $(\mathrm{T}-\mathrm{t}$ & $\mathrm{Sd}=130$ & $-1.345 ; \mathrm{p}=.181)$ \\
\hline \multirow{5}{*}{ No Worries } & Female & 57 & 2.610 & $\cdot 516$ \\
\hline & Male & 75 & 2.730 & .502 \\
\hline & (T-test: $\mathrm{Sd}=130 ;$ & $\mathrm{T}=-$ & $3 ; \mathrm{p}=.87$ & \\
\hline & Female & 57 & $2.45^{1}$ & $.428{ }^{*} \mathrm{p}<.05$ \\
\hline & Male & 75 & 2.463 & .432 \\
\hline \multirow[t]{3}{*}{ ESAPS Avg. } & (T-test: $\mathrm{Sd}=130 ;$ & $\mathrm{T}=-$ & $90 ; \mathrm{p}=.1$ & \\
\hline & Female & 57 & 2.700 & .281 \\
\hline & Male & 75 & 2.769 & .317 \\
\hline
\end{tabular}

Table-3:Psychological Skills Assessment Scale of the Athletes and the T-Test for the Sports Type Variable of its Sub-factors

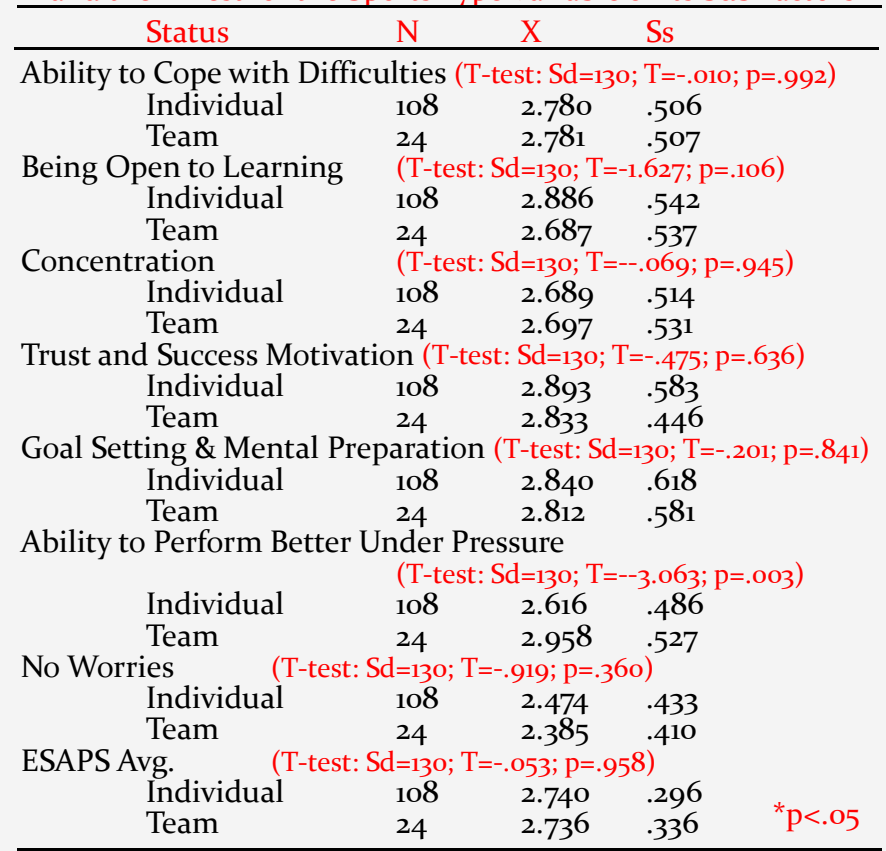

In terms of gender variable, it is clear that the "Concentration" sub-dimension is statistically significant when looking at the psychological skills sub-dimensions and average values of the psychological skills of the athletes participating in the study $(\mathrm{t}(130)=-2.606 ; \mathrm{p}=.011)$. We can say that this significance is due to the high average scores of male participants. No significant difference has been found between the genders in the mean score values and other sub-dimensions (Table-2).

It is understood that the sub-dimension of " Ability to Perform Better Under Pressure" is statistically significant ( $(130)=-2.606 ; p=.011)$. We can say that this significance is due to the high average scores of those who do team sports. No significant difference has been found between the other sub-dimensions and the average score values (Table-3).

Table-4: . The Five-Factor Personality Traits Scale of the Athletes and the ANOVA Test for the Age Variable of its Sub-Factors

\begin{tabular}{|c|c|c|c|c|}
\hline $\begin{array}{l}\text { Variance } \\
\text { Source }\end{array}$ & $\begin{array}{l}\text { Sum of } \\
\text { Squares }\end{array}$ & Std. & $\begin{array}{l}\text { Mean of } \\
\text { Squares }\end{array}$ & \\
\hline \multicolumn{5}{|c|}{ Extraversion $(\mathrm{F}=2.800 ; \mathrm{P}=.065)$} \\
\hline Intergroup & 2.013 & 2 & 1.006 & \\
\hline In-group & 46.364 & 129 & .359 & \\
\hline Total & 48.376 & 131 & & \\
\hline \multicolumn{5}{|c|}{ Emotional Stability $(\mathrm{F}=3.124 ; \mathrm{P}=.047 ;$ Diff. $=1>2)$} \\
\hline Intergroup & 1.818 & 2 & .909 & \\
\hline In-group & $37 \cdot 529$ & 129 & .291 & \\
\hline Total & $39 \cdot 347$ & 131 & & \\
\hline \multicolumn{5}{|c|}{ Openness to Experience $(\mathrm{F}=.080 ; \mathrm{P}=.924)$} \\
\hline Intergroup & .037 & 2 & .019 & \\
\hline In-group & 30.337 & 129 & .235 & \\
\hline Total & 30.375 & 131 & & \\
\hline \multicolumn{5}{|c|}{ Agreeableness $\quad(\mathrm{F}=.676 ; \mathrm{P}=.511)$} \\
\hline Intergroup & .544 & 2 & .272 & \\
\hline In-group 51.911 & 129 & .402 & & \\
\hline Total & 52.454 & 131 & & \\
\hline \multicolumn{5}{|c|}{ Self-discipline $\quad(\mathrm{F}=.736 ; \mathrm{P}=.481)$} \\
\hline Intergroup & .426 & 2 & .213 & \\
\hline In-group & $37 \cdot 359$ & 129 & .290 & \\
\hline Total & 37.786 & 131 & & \\
\hline \multicolumn{5}{|c|}{ FFPI Avg. $\quad(\mathrm{F}=.596 ; \mathrm{P}=.553)$} \\
\hline Intergroup & .103 & 2 & .051 & . \\
\hline In-group & 11.139 & 129 & .086 & \\
\hline Total & 11.242 & 131 & 1.006 & ${ }^{*} \mathrm{p}<.05$ \\
\hline
\end{tabular}

1: 11-18 years old. 2: 19-22 years old. 3: 23-26 years old.

A statistically significant difference has been found in the mean scores of the "Emotional Stability" sub-dimension (F (129) = 3.124, $\mathrm{p}=.047$ ). As a result of the Tukey multiple comparison test, which was conducted to determine the age groups of this difference (in other words, from which groups the difference stems), it has been found that the difference was between 15-18 years old athletes $(X=3.0457)$ and $19-22$ years old athletes $(X=$ 2.8138). According to these results, emotional stability grades increased positively as the ages of the athletes decreased (Table-4).

\section{Discussion and Conclusion:}

In this part of the study, the relationship between psychological skills of the athletes and five personality traits regarding such features as age, gender, sports, education, branch, sport duration, and sport starting age, administrative positions, and income has been analyzed according to various demographic variables in Turkey Olympic Preparation Center (TOPC) in Ankara. Then, findings have been discussed in the light of the literature. 
In the study, Psychological Skills and ${ }_{5}$ FKE subdimensions have been used together. In the research conducted, 132 athletes, 57 (43.2\%) female, and 75 (56.8\%) male constitute the samplegroup of the study.

When the average value of the athletes' psychological skills with personality traits sub-dimensions in Turkey Olympic Preparation Center (TOPC) in Ankara in terms of the sports type variable is considered, the "Ability to Perform Better Under Pressure" sub-dimension appears to be statistically significant $(\mathrm{t}(130)=-\mathbf{2 . 6 0 6} \mathrm{p}=0.011)$. This significance is derived from the average scores of those who do team sports are higher than those who do individual sports. We can say that athletes interested in individual sports are affected more by external and internal pressure factors and this is reflected in their performance. No significant difference has been found between the other sub-dimensions and the average score values. When the five-factor personality traits sub-dimensions and the average values of the athletes participating in the study have been taken into consideration in terms of the sport type variable, it has been found that there is no significant difference.

According to ANOVA analysis which is done to determine the difference between psychological skills subdimensions and the average point of athletes in terms of age variable in Turkey Olympic Preparation Center (TOPC) in Ankara, there has been statistically no significant difference. In terms of age variable, a statistically significant difference has been found in the mean scores of the "Emotional Balance" sub-dimension as one of the fivefactor personality traits sub-dimensions considering Anova analysis to determine the difference between the five-factor personality traits sub-dimensions and the average score values of the athletes participating in the study $(\mathrm{F}(129)=$ 3.124, $\mathrm{p}=0.047$ ). As a result of the Tukey multiple comparison tests, which was conducted to determine which age groups cause this difference (in other words, from which groups the difference stems), it has been found that the difference is derived from the athletes between 15 -18 years old $(X=3.0457)$ and $19-22$ years old $(X=2.8138)$. According to these results, emotional stability grades increased positively as the ages of the athletes decreased.

When the personality traits of athletes aged 18 and younger differ positively from athletes in other age groups in the sub-dimensions of responsibility and openness to development in the study titled "The Relationship between Coaches and Personality Traits on Motivation in Winter Sports" conducted by Agduman (2018). While the athletes in this group had the highest average score in the extraversion sub-dimension, it has been found that athletes aged 27 and over differed negatively from the other groups in the extraversion sub-dimension. Considering the significance of the different sub-dimensions of the FiveFactor Personality Traits, comparing the results of
Agduman's study with the results of our study, we can say that this difference is based on the age ranges of the athletes participating in the study and the sports branch types they have done.

Özer (2019) found no significant difference between the educational status of extreme athletes and their personality and sub-dimensions. These findings are not in linewith our study.

According to ANOVA analysis which is done to determine the difference between psychological skills subdimensions and the average point of athletes in terms of branch variable, it has been found that a statistically significant difference has been found between the subdimensions of "Being Open to Learning" $(\mathrm{F}(124)=3.722$, p $=$, oo1), "Goal Setting and Mental Preparation" $(\mathrm{F}(124)=$ $4,388, p=, 000)$ and the mean scores of ESAPS puanlarinda $(F(124)=4,252, p=, 000)$. In terms of branch variable, no difference has been found between the five-factor personality traits sub-dimensions and the average score values of the athletes participating in the study.

Coskun (2018) found in his study that there were statistically significant differences at $\mathrm{p}<.05$ level between the groups in all factors and general levels of the psychological skill levels of football players according to the sports age variable. While the results of the study are similar to the results in the sub-dimensions of "Being Open to Learning" and "Goal Setting and Mental Preparation" subdimensions of the psychological skills in our study, it is seen that there is a difference in theoverall mean scorevalues.

Consequently, the athletes staying in the Olympic preparation centers should be prepared not only with their muscle strength but also with mental training to prepare them for competitions and successful social life. This study, which is limited to the province of Ankara, can be diversified by applying to athletes in different branches in TOPC in different provinces. At the same time, since the athletes staying in TOPC vary every year, this and similar studies can be carried out again by referring to this study. In this way, the psychological skills and personality traits of the athletes staying in TOPC can create generalization norms.

\section{References:}

Agduman, F. (2018): Antrenör sporcu ilișkisi ve kişilik özelliklerinin kış sporlarında motivasyona etkisi. Yüksek Lisans Tezi. Atatürk Üniversitesi, Kış Sporları ve Spor Bilimleri Enstitüsü, Erzurum.

Akoğuz-Yazıcı, N., Kalkavan, A. \& Özdi-lek, Ç. (2016): An analysis on the attitudes of college students to physical education and sport pedagogy course in terms of some variables. Int. J. Sport Cult. Sci., 4(2):404-411.

Altıntaş, A. \& Akalan, C. (20o8): Zihinsel antrenman ve yüksek performans. Beden Eğitimi ve Spor Bilimleri Dergisi, 6(1):3943.

Altun, M. \& Koçak, S. (2015): Türkiye’nin sportif başarı açısından 
değerlendirilmesi: Bakü Avrupa Oyunları örneği. Spor Bilimler Dergisi, 26(3):114-128.

Brewer, B.W. (2009): Handbook of sports medicine and science sport psychology. Pub. by: Blackwell Publishing: 1-6.

Coșkun, K. (2018): Amatör ve profesyonel futbolcuların psikolojik beceri düzeylerinin ölçülmesi. Sağlık Bilimleri Enstitüsü. Beden Eğitimi ve Spor Anabilim Dali, Yüksek Lisans Tezi. Atatürk Üniversitesi. Erzurum.

Cüceloğlu, D. (2009): İnsan ve davranıșı. Pub. by: Remzi Kitapevi, 18. Baskı, İstanbul.

Danacı, M. (2008): Adana ilinde farklı tipteki liselerde öğrenim gören adolesan dönemi sedanter ve spor yapan erkek öğrencilerin spora yaklaşımı, fiziksel yapıları ve fizyomotorik özelliklerinin saptanması. Yüksek Lisans Tezi. Çukurova Üniversitesi, Sağlık Bilimleri Enstitüsü, Adana.

Devlet Planlama Teşkilatı. (200o): Spor ve İstanbul olimpiyatları özel ihtisas komisyonu raporu. DPTYayını. Yayın No:2513.

Erhan, S.E., Deniz, B., Güler, M.Ș. \& Ağduman, F. (2015): Sporcuların psikolojik becerilerini değerlendirme ölçeği'nin türkçe geçerlilik güvenirlik çalıșması. J. Phys. Edu. Sport Sci., 1:58.

Evinç, G.G. (2004): Çocuktaki dikkat eksikliği hiperaktivite bozukluğu (DEHB) ve eșlik eden belirtiler ile ilișkili olarak anne kișilik özellikleri, duygulanım durumu ve psikopatolojisi. Yüksek Lisans Tezi. Orta Doğu Teknik Üniversitesi, Sosyal Bilimler Enstitüsü, Ankara.

Feist, J. (1990): Theories of personality. Mc Neese State University, p.18.

İlhan, L. (2008): Eğitilebilir zihinsel engelli çocuklarda beden eğitimi ve sporun sosyalleşme düzeylerine etkisi. Kastamonu Eğitim Dergisi, 25(2):315-324.

Kıncal, R. (2015): Bilimsel araştırma yöntemleri. (4. Basım). Pub. by: Nobel Yayinevi, Ankara.

Koruç, Z. (1998): Yeni bir alan egzersiz ve spor psikolojisi. Türk Psikoloji Bülteni, 10:76-92.

Milavić, B. (2013): The psychological characteristics questionnaire for volleyball: development and validation -unpublished doctoral disertation [In Croatian]. University of Split, Faculty of Kinesiology, Split.

Milavic, B., Jurko, D. \& Grgantov, Z. (2013): Relations of Competitive State Anxiety and Efficacy of YoungVolleyball Players. Collegium Antropologicum, 37(2):83-92.
Moller, N. (1975): Olympic education. Sport J., 20:1543-9518.

Moran, A.P. (2004): Sport and exercise psychology: a critical introduction. 1st edt. Pub. by: London, Routledge press.

Murathan, T. \& Murathan, F. (2019): Blockchain applications in sports sector.Gaziantep Univers. J. Sport Sci., p: 65.

Murphy, S.M. \& Jowdy, D.P. (1992): Imagery and mental practice, pp-221-250. In: Horn TS (ed). Advances in Sport Psychology, 1st edt.Pub. by: Champaign, Illinois: Human Kinetics.

Olimpik Hazırlık Merkezlerinin Kuruluş, Çalışma, Görev, Yetki ve Sorumluluk Yönetmeliği (2015,11 Nisan). Resmi Gazete (Say1:29323).

Özer, H. (2019): Ekstrem sporcuların kișilik özelliklerinin incelenmesi. Yüksek Lisans Tezi. Muğla Sıtkı Koçman Üniversitesi, Sosyal Bilimler Enstitüsü. Muğla.

Smith, R., Schutz, R., Smoll, F. \& Ptacek, J. (1995): Development and validation of a multidimensional measure of sportspecific psychological skills: the athletic coping skills inventory-28. L. Sport Exer. Psychol., 17:379-398.

Somer, O., Korkmaz, M. \& Tatar, A. (2004): Kuramdan uygulamaya beș faktör kișilik modeli ve beș faktör kișilik envanteri (5FKE). İzmir, Ege Üniversitesi Yayınları, s.1, 13-28, 47-49.

Suinn, R.M. (1980): Psychology and sports performance principles and applications pp-26-36. In: Suinn RM. Psychologyc in Sport: Methods and Applications, 1st edt. Pub. by: Burgess Press, Minneapolis.

Tabachnick, B.G,. \& Fidell, L.S. (2013): Using Multivariate Statistics (6th ed.), Pub. by: Allyn and Bacon, Boston, M. A.

Vanek, M. \& Cratty, B.J. (1970): Psychology and the superior athlete. Pub. by: London; The Mc Millan.

Weinberg, S.R. \& Gould, D. (2015): Foundation of sport and exercise psychology champaign. Pub. by: Human Kinetics, 6th Edt.

Yanbastı, G. (1996): Kişilik kuramları, Ege Üniversitesi Edebiyat Fakültesi Yayınları, s.7-12, 252.

Yazici, A.G., Ogan, M., Öztürk, M.E. \& Özdemir, K. (2019): Student attitudes towards basketball. J. Physic. Edu. Res., 6(1):42-48. 